\title{
KOREANIC LOANWORDS IN KHITAN AND THEIR IMPORTANCE IN THE DECIPHERMENT OF THE LATTER
}

\author{
ALEXANDER VOVIN \\ EHESS/CRLAO, Paris \\ 54 Bd Raspail 75006 Paris, France \\ e-mail: sashavovin@gmail.com
}

In this article I am surveying several possible loanwords from Koreanic languages (probably Koguryǒ and/or Bo-hai) into the Khitan language. Apart from explaining the origin of some of the Khitan words that have no Mongolic, other Central Asian, or Chinese etymologies, I will demonstrate that these loanwords can shed light on the decipherment of Khitan characters with unknown readings, and therefore advance the reconstruction and reading of the Khitan language itself.

Key words: Khitan, Late Old Korean, Middle Korean, decipherment, reconstruction.

Despite that it is quite clear now that Khitan is a para-Mongolic language, related to the mainstream Mongolic, the amount of deciphered Khitan words that cannot be identified as Mongolic is quite significant. This probably should come as no surprise, because Khitans as the major power on the steppe were the successors to Old Uighurs and Qyrghyz in the West and to Bohai (Jpn. Bokkai, Kor. Parhae 渤海) in the East. I have attempted to demonstrate earlier that Khitan has some identifiable Old Turkic loanwords (Vovin 2013). This article has a goal to show that lexical influence from the East, namely from Koreanic, was also present. Again, this seems to be quite logical, because the old tribal territory of the Khitan was in Jehol (Wittfogel-Fêng 1949, p. 5). While the exact extent of the Koguryǒ ${ }^{1}$ domination in Manchuria is not known, it is almost certain that at least the Eastern part of Jehol was once under its sway.

We do not know exactly from which Koreanic language Khitan borrowed. It is likely that it was either the language of the Koguryor or the Bohai elites, or both. In absence of a second independent evidence, as well as due to the fact that even Old Korean, let alone the languages of Koguryǒ and Bohai, are attested very fragmentarily,

${ }^{1}$ Contrary to Beckwith (2004), it appears that the elite of Koguryǒ was Korean-speaking (Vovin 2005). 
the comparisons offered below are based mostly on the Middle Korean language of the 15 th -16 th centuries A.D.

(1) Khitan 叉冬欠 <m.as.qó> 'eldest son', 叉冬丈 <m.as.qú> 'eldest daughter' (Kane 2009, p. 95). Although Kane maintains that $<$ m.as.qu $>$ 'eldest, first' corresponds to Khitan 叉及 $<$ m.o> 'big, eldest, first' (ibid.), the exact nature of this correspondence remains unclear both phonologically and morphologically. In addition, Khitan $<$ m.as- $>$ does not really mean 'first', because it is used exclusively for the members of the family, as Kane himself notes (p. 98). For the time being it is better to view them as two unrelated words. The same should be said about Khitan 久 <qó > 'son' in 叉冬欠 <m.as.qó> 'eldest son' and 丹力 <bo.qo > 'child, son', especially because $<\mathrm{qo}>$ and $<\mathrm{qo}>$ are spelled with different phonograms.

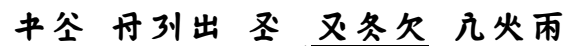

ai-d bo.hu.án $\mathrm{TWO}^{3}$ m.as.qó g.ui.in

male-PLUR child(PLUR) two eldest.son Guoyin (國鿵)

[He had] two male children; the eldest [was] Guoyin (YNM 26)

To the best of my knowledge there are no parallels to Khitan m.as- 'eldest' in other Mongolic languages: WM NF masi 'very, considerably' can be excluded on semantic grounds. However, MK 몯 mit $\sim$ 吴 mis 'eldest' coincides with the Khitan word almost exactly. There might be a slight problem here, though. The earliest MK texts prefer the spelling 몯 mit with final $-t$, but the later texts almost exclusively have the spelling 只 mis with final $-s$. However, it is well known that even in the earliest texts there was a strong tendency for neutralisation of all dental obstruents as [-t]. MdK has mat-, but other dialects provide evidence for both $-t$ and $-s$. Thus, the information is not conclusive, and it is difficult to make a final choice, although the coexistence of both $-t$ and $-s$ variants in the earliest texts probably points towards the neutralisation of $-s>-t$.

$$
\begin{aligned}
& \text { 모ㅇㅏㅏ·드:니·믄釋·셕迦가如셔來리시·고 } \\
& \text { mìt-àtí-nǐm-ín Syékkà Zyèrìy-[i]-sì-kó } \\
& \text { eldest-son-HON-TOP Śākya Tathāgata-[be]-HON-CONV } \\
& \text { [His] eldest son was Śākya Tathāgata, and ... (Welin 2: 1a) }
\end{aligned}
$$

(2) Khitan $₹<$ ai $>$ 'father' is a vexing word, because it can also mean 'male' with the following plural suffix $-d$, as the example in (1) above demonstrates, or in certain compounds, like $\neq \Omega<\mathrm{ai} \mathrm{ku}>$ 'husband', literally 'male person'. As Kane (2009, p. 100) noted, in Khitan transcriptions of Chinese ₹ is clearly [ai], as for example Khitan 汉 $\neq<$ k.ai $>$ standing for Chinese 開 $/ \mathrm{k}^{\mathrm{h}} \mathrm{ai} /$. However, it is not quite clear that the word for 'father' was pronounced in the same way. Kane (2009, p. 100) cites Toyoda (without providing an exact reference) who suggested the reading *awi for Khitan $₹<$ ai $>$ 'father' used as a logograph, and adds that there is no evidence for such a reading. 


\section{今币及公尔本及化中}

to.-do.ho n.on.-en u.ur a(w)i ${ }^{2}$

five-ORD generation-GEN top father

fifth generation forefather (XDM 3)

There are two oddities with this word. First, the same graph $₹$ was used to write Khitan <ai $>$ 'year'. Second, there are no etymologically cognate words for either $<$ ai $>$ 'father' or < ai> 'year' either in Mongolic, Turkic, Tungusic, ${ }^{3}$ or Chinese. But if Toyoda is right about the reading $* \mathrm{a}(\mathrm{w}) \mathrm{i}$, it is possible that Khitan $<\mathrm{ai}>$ 'father' is a loan from Koreanic, cf. LOK *api ( $Y$ 秘, Kyeylim \#137) and MK àpí (아·비).

그아·비·는 仙선 人신·올 니르·니·라

kù àpí-nón sènzìn-ír nìrù-n-í-rá

that father-TOP hermit-ACC say-PAST/ADN-be-FIN

'That father' referred to a hermit (Sekpo 11: 26a)

One obvious problem with this etymology is that $-p$ - in MK àpi' 'father' is a non-leniting $-p$-, that goes back to an *-Np- cluster (Vovin 2003). But, we do not know whether Khitan borrowed from a Koreanic language where PK *-Np- and *-p(> MK - $\beta$-) might have merged as *- $\beta$ - $\sim *_{-}^{*} \mathrm{~b}-$.

(3) Khitan ₹ <ai> 'year', briefly mentioned in (2) above does not have either Mongolic, or Turkic, Tungusic or Chinese etymologies.

\section{奀忝中全}

EIGHT is ai-se

EIGHT nine year-PLUR

eight-nine years (XZM 3$)^{4}$

It is likely that Khitan $/ \mathrm{h} /$ was a velar $/ \mathrm{x} /$, and not a laryngeal fricative $/ \mathrm{h} /$. In this case, it is possible to explain it as a loan from Koreanic, cf. MK híy ('히) 'year', where $/ \mathrm{h} /$ is a laryngeal voiceless fricative that was likely simply ignored in the process of borrowing.

여·슷·살ㄹㄹ 苦:코行·ㅎㅎㅇ·후샤

yèsús híy-rír khǒhhíyng hí-sy-á

six year-ACC ascetic.life do-HON-CONV

[he] was leading ascetic life for six years (Sekpo 6: 4b)

(4) Khitan $\square<\mathrm{qi}>$ 'that' does not have any parallels in Mongolic, Turkic, or Tungusic languages. It may be a loanword from LMC 其 $k h i$ or EM 其 $k h i$ ' 'that' (Pulleyblank 1991, p. 245). Since Khitan does not have a contrast between /i/ and /i/, it is equally possible that it is a loan from Koreanic, cf. MK kì [kì] (그) 'that'.

${ }^{2}$ Cited from Wu-Janhunen (2010, p. 60), except for the tentative (-w-).

${ }^{3}$ Manchu ańa 'year' and its other Tungusic cognates are unlikely to be loans from Khitan.

${ }^{4}$ See Chinggeltei et al. (1985, p. 595). 


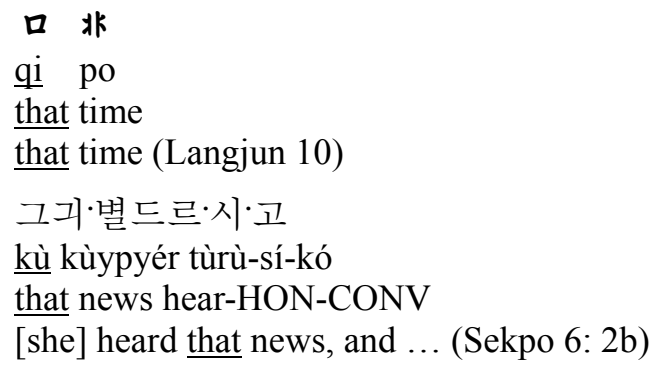

Now we come to two examples that demonstrate how the study of Koreanic loanwords in Khitan can potentially shed light on the decipherment of unknown readings for Khitan characters.

(5) Khitan 州久 < 188.qo> 'small'. Only the second character 久 $<$ qo $>$ has the established reading, but the reading of $⿻$ 州 (\#188) remains unknown. Kane (2009, p. 118) mentions that Aisin Gioro suggests *od, and Chinggeltei *ba (cf. Mongolian baya 'small'). The first of those seems to be completely ad hoc. The second is possible, but both the difference in vocalism and the shift $-q->-\gamma$ - remain to be explained. Kane (2009, p. 118) himself opts for the mnemonic reading <zỏ> on the basis of Chinese 州 'region, province'. Pulleyblank (1991, p. 411) reconstructs both LMC and EM readings of 州 'region, province' as $t s i w$, but this is clearly idiosyncratic, as it does not explain final $-\partial w$ in Modern Mandarin zhōu. Cf. the much more balanced Schuessler's (2009, p. 173) EMC tśjju, or Stimson's (1966, p. 208) EM t́śritul.

\begin{tabular}{|c|c|c|}
\hline 州久 & 机劣办劣 & 为共 \\
\hline$\underline{188 . \text { qo }}$ & c.e.en.e & ś.a.ri \\
\hline small & Chene & court.attendant \\
\hline
\end{tabular}

Except for a possible but not perfect comparison with WM baya 'small', there are no other obvious Mongolic, Turkic or Tungusic parallels to Khitan 州久 <188.qo> 'small'. However, if one follows Kane's suggestion about the mnemonic nature of the reading of Khitan, and reads it with the more appropriate ${ }^{*}$ cəw rather than $<$ zó $>$, the most obvious parallel is from Koreanic. There are MK doublets cyăk- (:쟉-) and cyěk- (:젹-), both with the RISING tone (denoted in the script by :), which indicates original disyllabic origin, thus cyăk- $<*$ cyak $\Lambda$ - and cyěk- $<*$ cyeke-. There are also two oddities concerning these doublets. First, it is highly unusual for MK spelling $<\mathrm{cy}->$, which probably renders $\mathrm{MK}[\check{\mathrm{c}}$ ], since $\mathrm{MK}<\mathrm{c}>$ (大) was [c]. Second, the alternation $a \sim e$ in MK normally occurs in cases of semantically 'heavy' and 'light' shades of meaning, like 'blue' and 'bluish'. Here, however, the words in question are complete doublets with no variation in meaning. This leads me to the conclusion that the archetype vowel was most likely the diphthong * ${ }^{\prime} \Lambda$ ( ! ), that in MK was present only in the speech of children and in peripheral dialects (Hwun-hay 23a).

\footnotetext{
${ }^{5}$ Cited from Kane (2009, p. 118).
} 
퀴:쟈글.씨

khúy cyăk-ìr ssíy

height be.small-IRR/ADN because

because [his] height was small (Sekpo 24: 8a)

혼.모.미.크.락:져그.락.호.야

hìn móm-í khú-r-ák cyěk-ùr-ák híy-í

one body-NOM be.big-IRR/ADN-POSTMOD be.small- IRR/ADN-

POSTMOD do-CONV

Whether a body is big or small (Welin 1: 14b)

Therefore, I suggest a tentative reading $<\mathrm{ca}>$ or $<\mathrm{co}>$ for the Khitan character 州. There might be a second independent piece of evidence in favour of this proposal. In line six of the Yelü Xiangwen epitaph studied and published by Wu and Janhunen (2010) we find the following two blocks:

\section{更化㕕矢头州夾籴中}

ś.ri.ge-de.i co.l.ha-ai

subtribal.group-ABL emerge-CONV

emerging from subtribal group(s)... (YXM 6-20/21)

Wu and Janhunen (2010, p. 150) explain Khitan 灭化矢头 as <́s.ri.ge.de.i>,

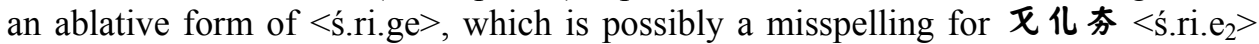
'subtribal group', but they only identify 州坐亚中<SMALL.1.ha.ai $>$ as a converb of some unknown verb. The identification of the Khitan character $\boldsymbol{N}$ as $<\mathrm{co}>$ allows to compare Khitan 州坐走 <co.l.ha-> with its potential cognate WM čolgi- 'to emerge [out of water]' (not attested in MM).

(6) Khitan 界丹<342.bo> 'wine'. The reading of the first character 界 \#342 is unknown. To the best of my knowledge, there are no possible Central Asian or Chinese etymologies of this word that would contain $<$ bo $>$ or $\langle$ bu $>$ as the second syllable. Since both Khitans during Liao and Jurchens during Jin were highly Sinicised, we can also suspect that here rice wine is meant, and not the Central Asian varieties of alcohol that were produced on the basis of other products.

\section{企办穴公去亩丹希机 em-en nai-d deu.úr 342.bo em-ci place-GEN official-PLUR together wine drink-CONV [he] drank wine together with the local officials, and ... (Langjun 4)}

However, there is a possible Koreanic etymology for Khitan 界 $<<342$.bo $>$ 'wine'. While the MK word for rice wine is :swur (:술), as I mentioned in (5) above, RISING tone always indicates disyllabic origin. Luckily enough, we have LOK attestation of the same word: 酥孛 swupo [subo] (Kyeylim \#187). ${ }^{6}$ If my identification

${ }^{6}$ It is unclear how MK :swur acquired its final $-r$, but it is quite apparent that LOK swupo [subo] could not have it, in spite of anachronistic transcriptions adopted by some Korean scholars, 
of the origin of Khitan 界丹 $<342$.bo > 'wine' as < subo> is correct, then Khitan 界 \#342 must have the reading $<$ su $>$. Consequently, we can obtain the following readings for the blocks listed below with their attestations:

(a) 界 青 342-311<subo> 'wine'. Beside Langjun 4-10 already discussed above, it also occurs in XWM 59-21, followed by three other blocks 59-22/24, which are all readable, ${ }^{7}$ but only one could be almost perfectly understood:

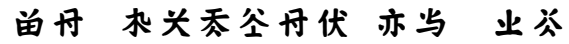 \\ subo c.i.is-d-bo.ń un.én p(o)-er \\ wine blood-VRB/PASS-PERF/ADN truth? COP-PAST? \\ it was indeed that [they] added blood to wine (XWM 59-21/24)}

This clearly describes the ceremony of mixing wine with sacrificial blood, mentioned in a translation by Wittfogel and Fêng (1949, p. 271): "On the day of the winter solstice, as a national custom, a white sheep, a white horse, and a white goose were slaughtered. The blood of each was taken and mixed with wine. Then the Son of Heaven worshipped the Black Mountain from a distance".

Khitan 机头忝 <c.i.is> is 'blood', 丹伏 <-bon'> is a perfective marker, which according to Kane $(2009$, pp. 147, 155) can also form verbal nouns, although looking at his example (on p. 155) it should rather be treated as an adnominal form. Then $<-d->$ must be some kind of verbaliser with the passive meaning not mentioned in Kane's (2009, pp. 131-166) sketch of the Khitan morphology. The remaining two blocks are also readable, but by no means clear. The last one could be potentially the past tense in 公 $<$-er $>$ of the copula $\boldsymbol{\mu}$ 及 $<\mathrm{p}(\mathrm{o})$. u $>$, but $\boldsymbol{\mu}$ 及全 $<$ p.o-or $>$ (Kane 2009, p. 146) should be rather expected. It is possible that the third block 亦与 $<$ un.én $>$ is a cognate of MM and WM ünen 'truth'. Then the verbal form 机头冬父母伏 $<$ c.i.is-dboń> is likely to be an adnominal, therefore, I arrive at the tentative interpretation and translation presented above.

(b) According to Chinggeltei et al. (1985), the Khitan character 界 $<$ su $>$ also occurs in two other blocks. The first of them is 界业术 342-295-140 (XZM 3-54) which I propose to read as $<\sup (0)$-en $>$, since $\boldsymbol{\mu} \# 295$, usually read as $<\mathrm{p}>$, is also read as $\langle$ po $\rangle$ on at least one occasion: there is a spelling alternation 业及 po.o 业及及 p.o.o 'monkey' (Kane 2009, p. 70). Since there is a variation between [p] and [b] in Khitan, cf. copula 业及 $<$ p(o).u $>\sim$ 丹及 $<$ b(o).u $>$ (Kane 2009, p. 156), I think there is a possibility that 界业本 342-295-140<sup(o)-en> (XZM 3-54) might be a

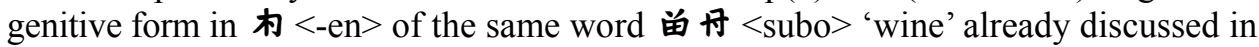
(a) above. However, it occurs in a much less clear context. Below I provide four relevant blocks (XZM 3-52/55): ${ }^{8}$

who read the transcription 酥孛 swupo [subo] as supur or suə-puət (Kang 1991, p. 71), because in the early 12th century the final EMC - $t$ or LMC $-r$ were no longer there.

${ }^{7}$ None of them was commented upon in Chinggeltei et al. (1985, p. 581).

${ }^{8}$ Neither Chinggeltei et al. (1985) nor Ji Shi (1991) comment on these blocks. 


\section{可公立万及干界业机节化}

kẻ-d-ha.a-lún ul su.p(o)-en cu.úd

bury-PASS-CAUS-PAST 366 wine-GEN 102.179

$\ldots$ of the wine ... that was made to be buried (XZM 3-52/55)

My interpretation and translation of these four blocks remain highly provisional, as there are several problems. First, although Wittfogel and Fêng (1949, pp. 278-283) mention that there were numerous libations during imperial funeral ceremonies, and that wine and food were burnt in front of the imperial mausoleum (p. 284), they remain silent on whether the wine was actually entombed with other goods together with the coffin in a mausoleum. Most likely it was, as their Figure 27 (on p. 282) presents a picture of a wine cup next to a wine jar, excavated from the imperial Liao tombs. Secondly, while the interpretation of the first block and the third block (as I believe) is easy and uncontroversial, the second and the fourth blocks, although readable, still represent puzzles. Thus, the third block consists of a single Khitan character $\mp$ \#366, with a known reading $<\mathrm{ul}>$, which frequently appears in the Khitan word 及 7 $<$ u.ul $>$ 'winter' that, to the best of my knowledge, is never spelled just $\mp<\mathrm{ul}>$. Moreover, although this character is known just as a phonographic one, the very fact that it takes the whole block to itself suggests logographic usage here. Possibly, it might be the name of a wine. Or it may be co-ordinative to 界业杫 < sup(o)-en> 'wine-GEN' and denote the name of another product that was also entombed. If Kane (2009, p. 111) is right that Khitan $\mathcal{x}<$ ui $>$ 'pig' may actually reflect *uil, the character $₹<$ ul $>$ could turn out to be an allograph of the same word. Since pork was one of the staple foodstuffs in Manchuria since time immemorial, the pairing of pork and wine as goods entombed with the deceased emperor really makes sense. The last block 5 亿 $<$ cu.úd $>$ formally looks like a plural in $-d$ of the noun *cu.u- with unknown meaning, but if my guess about the context here is right, then it probably means 'offering'. Consequently, these four blocks might be explained as 'entombed offerings of pork and wine', but the explanation, of course, remains speculative due to many unknown factors.

(c) The remaining block, where the Khitan character 界 $<$ su $>$ is used, 界公 $<$ su.er> 342-341 occurs twice (XWM 47-3, XZM 47-3). Apart from the observation that formally it looks like a past tense form in 会 <-er> of an unknown verb 界 *su-, I am unable to offer any other considerations at this point.

\section{Abbreviations}

\section{Languages}

$\begin{array}{ll}\text { EM } & \text { Early Mandarin } \\ \text { EMC } & \text { Early Middle Chinese } \\ \text { LMC } & \text { Late Middle Chinese } \\ \text { LOK } & \text { Late Old Korean } \\ \text { MdK } & \text { Modern Standard Seoul Korean }\end{array}$


$\begin{array}{ll}\text { MK } & \text { Middle Korean } \\ \text { MM } & \text { Middle Mongolian } \\ \text { PK } & \text { Proto-Koreanic } \\ \text { WM } & \text { Written Mongolian }\end{array}$

\section{Primary Sources}

Khitan

Langjun Dajin huang di dutong jinglüe langjun xing ji (大金皇弟都统经略郎君行记), 1134 A.D.

XDM Xiao Dilu Fushi muzhi (萧敵魯副使墓誌), 1114 A.D.

XWM Xu Wang muzhi (許王墓誌), 1109 A.D.

XZM Xiao Zhonggong muzhi (萧仲恭墓誌), 1150 A.D.

YNM Yelü Nu muzhiming (耶律奴墓誌銘), 1099 A.D.

YXM Yelü Xiangwen muzhi (耶律詳稳墓誌), 1091 A.D.

\section{Korean}

Hwun-hay Hwunmin cengum haylyey (訓民正音解例), 1446 A.D.

Kyeylim Kyeylim yusa Korye pangen (鶏林類事高麗方言), 1103 A.D.

Sekpo Sekpo sangcel (釋譜詳節), 1447 A.D.

Welin Welin sekpo (月印釋譜), 1459 A.D.

\section{Grammar Terms}

$\begin{array}{ll}\text { ABL } & \text { Ablative } \\ \text { ACC } & \text { Accusative } \\ \text { ADN } & \text { Adnominal } \\ \text { CAUS } & \text { Causative } \\ \text { CONV } & \text { Converb } \\ \text { COP } & \text { Copula } \\ \text { FIN } & \text { Final } \\ \text { GEN } & \text { Genitive } \\ \text { HON } & \text { Honorific } \\ \text { IRR } & \text { Irrealis } \\ \text { NOM } & \text { Nominative } \\ \text { ORD } & \text { Ordinal } \\ \text { PASS } & \text { Passive } \\ \text { PAST } & \text { Past tense } \\ \text { PERF } & \text { Perfective } \\ \text { PLUR } & \text { Plural } \\ \text { POSTMOD } & \text { Postmodifier } \\ \text { TOP } & \text { Topic } \\ \text { VRB } & \text { Verbaliser }\end{array}$




\section{References}

Beckwith, C. I. (2004): Koguryo: The Language of Japan's Continental Relatives. Leiden-Boston, Brill.

Chinggeltei-Liu F.-Chen N.-Yu B.-Xing X. (1985): Qidan xiao zi yanjiu. Beijing, Zhongguo shehui kexue chubanshe.

Ji, S. (1991): Mei lin wen jing. Shenyang, Liaoning minzu chubanshe.

Kane, D. (2009): The Kitan Language and Script. Leiden-Boston, Brill.

Kang, S. (1991): Kyeylim yusa "Kolye pangen" yenkwu. Seoul, Sengkyukwan tayhakkyo chwulphanpu.

Pulleyblank, E. G. (1991): Lexicon of Reconstructed Pronunciation in Early Middle Chinese, Late Middle Chinese, and Early Mandarin. Vancouver, University of British Columbia.

Schuessler, A. (2009): Minimal Old Chinese and Later Han Chinese. Honolulu, University of Hawai'i Press.

Stimson, H. M. (1966): The Jongyuan In Yunn. New Haven, Yale University Far Eastern Publications.

Vovin, A. (2003): Once Again on Lenition in Middle Korean. Korean Studies Vol. 27, pp. 85-107.

Vovin, A. (2005): Koguryǒ and Paekche: Different Languages or Dialects of Old Korean? Journal of Inner and East Asian Studies Vol. 2, No. 2, pp. 107-140.

Vovin, A. (2013): Old Turkic Loanwords in the Khitan Language. In: Şirin, U. H. - Gül, B. (eds): Yalım Kaya Bitigi. Osman Fikri Setkaya Armağanı. Ankara, Türk Kültürünü Araştırma Enstitüsü, pp. 621-625.

Wittfogel, K. A.-Fêng, C.-S. (1949): History of Chinese Society. Liao (907-1125). Philadelphia, The American Philosophical Society.

Wu, Y.- Janhunen, J. (2010): New Materials on the Khitan Small Script. Folkestone, Global Oriental. 